\title{
SMEs and Their Use of Intellectual Property Rights in Australia*
}

\author{
Paul H. Jensen and Elizabeth Webster \\ Melbourne Institute of Applied Economic and Social Research \\ Intellectual Property Research Institute of Australia \\ The University of Melbourne \\ Melbourne Institute Working Paper No. 17/04 \\ ISSN 1328-4991 (Print) \\ ISSN 1447-5863 (Online) \\ ISBN 0734031599
}

\begin{abstract}
August 2004
*The authors would like to thank John Creedy for comments on this paper. The genesis of this working paper was a consulting project commissioned by the Commonwealth Department of Industry, Tourism and Resources. Thanks must go to Rod Crawford, Sean Applegate, Paul Mills and Leanne McConchie from IP Australia for providing the data on registered intellectual property rights.
\end{abstract}

Melbourne Institute of Applied Economic and Social Research The University of Melbourne

Victoria 3010 Australia

Telephone (03) 83442100

Fax (03) 83442111

Email melb-inst@unimelb.edu.au

WWW Address http://www.melbourneinstitute.com 


\begin{abstract}
There is a common, largely anecdotally based belief that registered intellectual property is a less efficient form of protection for SME inventors compared with inventors from large firms. This paper discusses the reasons why SMEs may be disadvantaged in their use of intellectual property as opposed to more general disadvantages they may incur over the whole course of innovation. It estimates patent and trade mark rates per employee in Australia but does not find a significant difference between the large firm and SME sectors once industry effects are taken into account.
\end{abstract}




\section{Introduction}

This paper tests whether SMEs are disadvantaged in their use of intellectual property as opposed to more general disadvantages they may incur over the whole course of innovation. Conventional wisdom dictates that unfettered innovation markets fail to provide the optimal level of innovative services to the economy if innovating firms cannot appropriate enough profits, at the margin, to make the private returns to the investment equal the social returns. To remedy this market failure, governments in most countries have legislated for a system of intellectual property (IP) registration and enforcement to prevent imitation, (specifically patents ${ }^{1}$, trade marks ${ }^{2}$, copyright, registered designs, legal protection of confidential information, plant breeders' rights and circuit layout rights), in an attempt to enhance private returns. In practice, however, firms often rely on other appropriability mechanisms such as trade secrecy and first-mover advantages since the effectiveness of IP rights - particularly patents - may be poor in some industries and for types of technologies. ${ }^{3}$

The common perception is that the effectiveness of IP rights also varies according to firm size. Specifically, it is often argued that small-medium sized enterprises (SMEs) ${ }^{4}$ are disadvantaged vis-à-vis large firms in their ability to use IP rights to capture returns from

\footnotetext{
${ }^{1}$ Patents increase private returns by penalising and thus discouraging other firms who might copy the patented invention and thus erode the patentee's profits. An alternative rationale for the patent system, the "contract theory of patents" contends that governments support patent systems to encourage inventors to disclose more of their inventive step than would otherwise be apparent. The inventor receives a limited monopoly right as a quid pro quo for potential knowledge spillovers to other members of the economy (see Denicolo and Franzoni 2004). However, empirical evidence indicates that patent disclosures are a weak source of learning about new products and processes for firms (Levin et al. 1987b). We do not find this surprising since we expect that inventions that are hard to imitate have little need for patenting to stop copying, and thus will not be disclosed through the patent system. Conversely, those that are hard to conceal will tend to be patented. Thus the inventions that have the potential to impart the most knowledge spillovers through the patent system also have the most to lose through disclosure.

2 Trade marks provide firms with an incentive to invest in product quality to the extent consumers associate a particular type of product with a brand and are prepared to pay a premium for quality assurance. Firms are thus able to appropriate returns to their investment in product development.

${ }^{3}$ See the survey results from Levin et al. (1987b), Cohen et al. (2000) and the study by Nelson cited in Patel and Pavitt (1995).

${ }^{4}$ There is no single definition of an SME but the convention is to assume that it refers to an independent business below a certain size. In this paper, a small business is one that employs up to 20 people, while a medium size business is one that employs between 20 and 200 people and has assets under \$200m.
} 
their innovative efforts. The following statement is representative of the typical assertion made with regard to the problems SMEs face in using the patent system:

The patent system is not equally suited to all; it suits the pharmaceutical industry very well and most small firms very badly (Macdonald 2004).

While this view is largely based on casual empiricism, Arundel and Kabla (1998) recently provided some confirmatory evidence in a study that demonstrated that small European firms have a lower propensity to patent their innovations than large firms. Given the relative importance of SMEs in most economies, this suggests that an important source of creative potential in the economy may be neglected, thereby handing large firms a competitive advantage. If it can be substantiated that the IP system is not providing an effective means to counteract SMEs' potential under-investment in innovation, then an argument for further government intervention exists.

In order to analyse this issue, this paper examines industry views on the nature and extent of SME disadvantage and uses administrative data on the rates of usage of patents, trade marks and designs by SMEs and large firms in Australia to examine whether these concerns have any empirical basis. We begin this paper by defining innovation and examining the arguments for market failure in the innovation process. In section 3, we separate the innovation and appropriation process into two distinct stages and examine how size-related issues may affect a firm's decision-making in each of these stages. In section 4, we present data on the comparative usage of the IP system by SMEs compared to large firms. Finally, some conclusions are drawn.

\section{Innovation, market failure and SMEs}

Innovation is defined as the creation of a new idea, product or process. In this context, "new" could imply either something that is new to the world (i.e. an invention) or something that is simply new to the firm (i.e. an imitation). This distinction has an important bearing on how to measure innovation since some innovation indicators require newness to the world (e.g. patents) while others do not (e.g. trade marks). In his canonical text, Schumpeter (1934) discussed a number of dimensions of innovation including product innovation, process innovation, organisational innovation and market innovation. 
Since we are concerned in this paper with the use of the IP system as a means of enhancing firms' appropriability strategies, and most IP rights seek to prevent the imitation of product innovations (see Jensen and Webster 2004), our analysis primarily relates to product innovations. This type of innovation refers to the creation of new (or improved) goods or services that are launched on to the market. Whilst both goods and services are included in this aspect of innovation, much of the literature is dominated by innovations in physical goods.

Although it has come under attack in recent times (see Boldrin and Levine 2004), the prevailing view within much of the economic literature on innovation is that IP rights are an effective antidote to the comprehensive failure in the market for innovation. However, neither of the propositions contained in this statement are universally true: some industries do not appear to suffer from market failure, while others where market failure is a problem often find IP rights ineffective (see Mansfield et al. 1981 for example). Thus, there are two dimensions to analysing the innovation market failure problem: the first is the extent to which market failure exists in any sector or industry, and the second is the availability of suitable and efficient remedies.

Assuming that innovation is costly ${ }^{5}$, the extent of market failure in any given industry depends on the conditions of knowledge transfer, which can be represented by a continuum of the marginal costs of imitation. At one end of the spectrum - where the marginal costs of imitation are zero - are technologies that can be costlessly transferred through blueprints and codified formats or where reverse engineering is technically easy. Market failure is clearly a problem in this instance. At the other end of the spectrum where market failure is not a problem since the marginal costs of imitation are equal to the average cost of production - are technologies that rely on tacit knowledge that is typically embedded in human capital.

In circumstances where market failure is a problem, firms can attenuate its effects by raising the costs of imitation or preventing rivals from expropriating their profits. This

\footnotetext{
${ }^{5}$ If innovation is costless - for example, if it is a by-product of the normal production process (learning-bydoing) - then there is no market failure since there is no under-investment problem in this instance. While such serendipitous discoveries no doubt occur, many innovations involves ex ante investment.
} 
can be achieved in a number of different ways including the use of registered IP rights, secrecy, first-mover advantages and the production of non-imitable complementary goods and services. Governments can also seek to ameliorate innovation market failures by lowering the costs of creation through the use of R\&D grants and tax concessions. ${ }^{6}$ However, none of these measures are universally effective. Patents and trade marks, for example, are probabilistic in nature which means that there is no guarantee that a registered patent or trade mark will be found valid if challenged in a court of law. In addition, patents may be used by firms for strategic reasons such as submarine patents or the construction of patent thickets whose anti-competitive effects may overshadow any of the benefits attributable to stimulating innovation. With regard to government R\&D grants, there is some evidence to suggest that subsidies are often provided to firms to fund projects that are privately profitable and would be undertaken in the absence of any subsidies (see Wallsten 2000). Thus, public R\&D grants may have some undesirable effects such as crowding-out private R\&D investment.

In this light, public policy makers should only consider further government intervention in areas where it can be demonstrated there is both a reasonable level of market failure, where there are few existing and effective mechanisms available to firms to attenuate this failure and where the distortionary effects of any intervention are not too severe. If the conditions for ex ante market failure do not exist, then we should not be concerned about the lack of use by firms of the common forms of appropriability cited above. ${ }^{7}$ Similarly, the use of grants in these areas where there is no market failure represent a dead-weight loss which transfers public money to private firms, with no net positive effect on R\&D expenditure. However, in industries where the conditions for ex ante market failure do exist, the absence of effective means of appropriation implies that firms are underinvesting in innovation, ceteris paribus.

\footnotetext{
${ }^{6}$ Although these policy measures are commonly used to address the market failure problem, and in particular to assist SMEs in this regard (see Lerner (1999) for a discussion of the Small Business Innovation Research (SBIR) program in the US), they will not be discussed in any detail in this paper.

${ }^{7}$ In fact, the use of patents in this instance may represent a socially detrimental strategy to raise the cost of imitation above the original costs of creation (see Heller and Eisenberg 1998, Shapiro 2001, Rubinfeld and Maness 2004).
} 
In this paper, we carefully examine whether there is any empirical evidence supporting the view that SMEs are disadvantaged with regard to their ability to access one specific type of appropriability mechanism: IP rights such as patents, trade marks and registered designs. This is achieved by comparing the rate of usage of IP rights by both SMEs and large firms. However three important caveats must accompany our findings. Bearing in mind the discussion above, the first is that we cannot distinguish industries and sectors where market failure problems are known to be acute from those where it is less severe. Clearly, differential rate of IP usage in the latter industries is of less concern than the former. Secondly, our analysis of the mechanisms to correct for market failure is limited to IP rights since comprehensive data on the use of other forms of appropriation are not available. Accordingly, we cannot determine whether firms with lower IP rates compensate by using other forms of appropriability or simply have lower combined appropriability. While it is only the latter case that gives rise to public concern, we must treat the two as synonymous. A further limitation of the study is that even if we find evidence that SMEs are not able to fully exploit the IP system, it is not clear that social welfare has necessarily been compromised since large firms may exist comfortably in this production space and may already supply the market with the optimal level of innovation.

\section{Effects of firm size on innovation and IP usage}

Although the question of the relationship between firm size and innovation is wellresearched, the same cannot be said of the relationship between firm size and usage of the IP system. ${ }^{8}$ Those studies that have attempted to examine this (or closely-related) questions have often done so by simply comparing the number of IP rights held by large and small firms. Such an approach is flawed for two reasons. First, it fails to take account of the fact that it is the rate of usage not the absolute level of usage that is of interest: in absolute terms, large firms do more of everything by virtue of their size, so it should not surprise (or concern) us if empirical evidence confirms this. What is of interest is whether there are systematic differences in the number of IP rights per employee held by SMEs and large firms across a range of industries. Secondly, and more importantly, comparing

\footnotetext{
${ }^{8}$ The small number of studies include CHI Research (2003), Iversen (2002), Hanel 2004.
} 
the number of IP rights held by firms even after adjusting for size may lead to spurious conclusions if an objective measure of the level of innovation undertaken is not factored into the analysis. For example, a finding that SMEs patent less often than large firms need not be a concern if SMEs actually innovate less than large firms for reasons other than those concerned with the appropriation conditions of the IP system. If, on the other hand, it is known that SMEs are more innovative than large firms, the fact that they have the same propensity to patent may be indicative of a substantial problem.

In order to separate these two potentially conflating arguments, we need to understand how firm size affects innovation levels and how it affects IP usage. Accordingly, we draw a distinction here between different stages in the commercialisation process. The two stages considered here are referred to as the innovation decision and the appropriation decision, which are represented in Figure $1 .{ }^{9}$ Using backward induction to analyse the firm's decision-making process, we present the appropriation decision first followed by the innovation decision. That is, we assume that the firm's manager first considers the decision about how to appropriate profits given the outcome of the innovation process, and then analyses the decision to invest in the innovation process.

\subsection{The appropriation decision}

The decision to develop and commercialise a promising innovation depends partly on how efficiently a firm believes it can prevent others from expropriating its returns. Firms have a number of different mechanisms available to them that enable them to recoup their investment including the use of registered IP rights, trade secrecy and first-mover advantages. We have called the choice between these different mechanisms "the appropriation decision". This decision may be influenced by the characteristics of the firm (such as its size or ownership) and characteristics of the product (such as its imitability or the technology's codifiability). There are also strategic issues that affect the appropriation decision since it is linked to the decision about whether to enter the product market directly once an innovation has been developed. For example, if a firm has

\footnotetext{
${ }^{9}$ Note that in order to simplify exposition, we have assumed in our two-stage representation of the process that the two decisions are sequential in nature and that there are no feedback loops. Although neither of these assumptions hold in reality, their introduction does not introduce any loss of generality.
} 
developed a product which has many competitors, it may decide to license the commercialisation of the product to others rather than enter the product market directly. If it does so, it may choose to register the IP embodied in the product since one of the advantages of registering an IP right is that it provides firms with leverage during licensing negotiations and decreases the likelihood that the invention will be expropriated by the other party. ${ }^{10}$ This may be particularly important for SMEs since they may be more likely to seek cooperative arrangements with large firms in order to avoid duplication of investments such as distribution and marketing that are necessary in order to commercialise an innovation (see Gans et al. 2002).

In this paper, it is only the size-related issues that are of interest. Of particular interest is whether differences in the use of the IP system across firms of different size arise from a bias in the design of the IP system against SMEs. There are a number of reasons - all of which are related to cost - why such a bias might arise. First, registration of an innovation is costly. These costs relate to both the costs incurred in demonstrating that the innovation meets the necessary registration threshold and the registration fee payable (and periodic maintenance fees) once registration has been approved. ${ }^{11}$ Both dimensions of the registration costs typically involve substantive legal fees. Although all firms incur this cost, it is a non-trivial fixed cost that bears a disproportionate burden on firms with smaller production runs.

Secondly, IP rights are costly to enforce. The owner of an IP right may need to engage in costly dispute resolution if the validity of the IP right is challenged or if the owner alleges that other firms have infringed its IP. However, the cost of enforcement may be a decreasing function of size since firms with large IP portfolios may be able to reap economies of scale through the employment of in-house IP professionals and this should

\footnotetext{
${ }^{10}$ While this is true for patents, designs and copyright, it is less obvious that trade marks have any value in licensing negotiations since trade marks play a different role in protecting investments than other types of IP rights. Trade marks are simply used to distinguish one firm's products from a rival's products. This assists consumers to learn, classify and recognise the unobservable characteristics of the product and in so doing, trade marks lower consumer search costs and provide firms with an incentive to invest in product quality (Economides 1997).

${ }^{11}$ Note, however, that the magnitude of these costs varies according to the type of IP right: patents have the highest threshold (non-obviousness, novelty and utility), are the hardest to examine and therefore incur the highest registration fees. Copyright, on the other hand, requires no registration fee since it is assumed that all written (and other types of) material is copyrightable.
} 
lower the costs of both IP usage and enforcement. While these costs are only incurred in a small proportion of cases, recent evidence suggests that they can be very expensive: patent litigation cases in the US, for example, cost each party in the dispute an average of US\$3-4 million [IPAC 2003, 13 and Appendix 2].

Although the magnitude of litigation costs is likely to vary across industry and technology types (see Cooter and Rubinfeld 1989), it seems that in many instances SMEs may simply not have the resources to fund such dispute resolution procedures since they cannot deal with the ex ante risk of litigation by pooling risk across a number of product lines. Scherer and Ross (1990) state that:

Small firms are at a severe disadvantage trying to claim patent rights, or enforce them against larger rivals who better able to sustain the multimillion-dollar costs of a protracted patent litigation. Thus, even though they need patent protection more than well-established companies, the protection they actually receive is more fragile (pp. 629-630).

The sheer scale of potential litigation costs introduces a strategic component into dispute resolution processes that may also adversely affect SMEs. Coupled with the inherent uncertainty in the outcome of court proceedings, the potential cost of litigation could induce large firms to deliberately draw out dispute resolution proceedings with SMEs thereby forcing them to accede to unfavourable settlement terms. That is, large firms can credibly threaten SMEs (and thus weaken their leverage in any negotiations) even in instances where their claim to ownership of an IP right may be weak.

\subsection{The innovation decision}

Given that a firm believes that it can find an efficient mechanism to appropriate the wealth generated by an innovation, it then needs to decide whether to make the necessary investment to convert its latent innovative potential into an actual innovation or whether to simply carry on with its existing production process. We refer to this decision here as "the innovation decision". The innovation decision has been well-researched by economists, with numerous articles examining whether factors such as firm size and market structure affect a firm's decision to innovate. 
Ignoring the market structure factor, let us take a closer look at the firm size effect.

Following Schumpeter (1934), it is typically argued that large firms are more innovative since they have the retained earnings with which to re-invest in risky innovative activities. However, a contrary argument is that SMEs may have some distinct advantages in innovation since they may have better information about the function that relates expected profitability of an innovation to development expenditure (see Arrow 1983 ) and that they may have less inertia than large firms and are therefore able to recognise (and take advantage of) market niches (see Rogers 2004). Given these countervailing arguments, it is perhaps not surprising that the empirical literature on the relationship between firm size and innovative is inconclusive. Despite this, it is worth reflecting further on the rationales for the hypothesis that firm size can adversely affect the innovation decision.

There are three established a priori reasons why SMEs may be disadvantaged, vis-à-vis large firms, with regard to the innovation decision. First, there may be economies of scale in $R \& D$ production and the innovative process more broadly. ${ }^{12}$ If true, this implies that the marginal cost of innovation will be smaller for large firms. However, the current consensus in the empirical literature is that this only holds consistently across different industries: within an industry, size does not matter. ${ }^{13}$ In industries where an R\&D minimum efficient scale (MES) exists, large companies will be better placed than SMEs. Secondly, innovation is more cost efficient when firms are able to amortise the fixed innovation costs over larger production runs (Schumpeter 1976, Cohen and Levinthal 1989). ${ }^{14}$ Given that large firms typically have larger production runs (and therefore revenues) than SMEs, this suggests that large firms will be more able to spread the fixed costs of innovation thereby lowering the average total cost of a given innovation.

\footnotetext{
${ }^{12}$ Much of these economies are gained because knowledge acquisition is often a fixed cost.

${ }^{13}$ Patel and Pavitt (1995) for example argue that large R\&D laboratories are required for innovation in the chemical and electrical-electronics area but not for mechanical and ICT areas. See also Levin et al. (1987a), Acs and Audretsch (1993), Kleinknecht et al. (1993), Cohen (1995). The survey by Levin and Reiss (1984) suggests that the inconclusive results may arise because the MES is low for many technologies.

${ }^{14}$ This will also depend on the elasticity of market demand for the product and thus the trade off between the size of the production run and the profit mark-up.
} 
Thirdly, many SMEs face binding capital constraints and are small simply because their owners do not have significant financial and tangible assets. For both large firms and SMEs high-risk investments that produce no mortgageable assets, such as inventive activities, are more likely to attract a high risk premium if finance externally. Managers therefore will prefer to use retained earnings, ceteris paribus. Whereas large firms are often able to fall back of either significant retained earnings or can borrow or raise equity at a cheaper rate on the strength of their substantial assets, SMEs may not have the capacity to do so. This pattern is supported by the data in Table 1 which shows that assets per employed person is considerable higher in the large firm sector than the SME sector.

\section{Data and empirical analysis}

If SMEs are disadvantaged in their ability to use the IP system (and indeed IP is effective in enhancing private appropriability), then the SME sector should have a lower rate of actual to potential innovation, as well as a lower rate of IP usage to potential innovation. Unfortunately, a dataset comprehensive enough to produce these types of rates does not exist in Australia. Instead, we have collated Australian firm-level data on most of the important areas: potential innovativeness (as measured by employment ${ }^{15}$ ), firm size (as measured by the number of assets and the number of employees) and IP rights (counts of patents, trade marks and registered designs). The only link that is missing is an independent measure of firm-level innovation. While a lower rate of IP usage to employed persons for SMEs may reflect their disadvantage in the use of the IP system, it is also consistent with a lower level of actual to potential innovativeness arising from other size disadvantages discussed in section 3.2.

Unfortunately, we are not able to distinguish between these two cases. Nonetheless, in order to derive this ratio, we have combined IP and enterprise data from four separate sources. The first dataset used to analyse this issue were collected from the Australian Bureau of Statistics (ABS), which provides data on the breakdown of firms (by size, value-added and assets) across industries. According to the data presented in Table 1,

\footnotetext{
${ }^{15}$ Since all inventions and innovations emanate from people, not machines, we assume that a firm's latent potential to innovate related to the number of people it has working for it.
} 
99.5 per cent of all firms are SMEs ${ }^{16}$ and they accounted for 61.8 per cent of employment, 49.4 per cent of value added and 14.6 per cent of business assets in 200001. Thus, it appears that while SMEs are numerous in Australia, it is the large firms that are asset-rich and contribute most to value-added.

Table 1: Profile of Large firms and SMEs ${ }^{(a)}$, Australia, 2000-01

\begin{tabular}{l|rrrr}
\hline & \multicolumn{4}{|c}{ Firm Size } \\
& \multicolumn{1}{|c}{ Large } & \multicolumn{1}{c}{ SME } & Large (\%) & SME (\%) \\
\hline Operating businesses (no.) & 3,229 & 607,663 & 0.5 & 99.5 \\
Total employment ('000) & 2,436 & 3,944 & 38.2 & 61.8 \\
Total value added (\$m) & 189,892 & 185,471 & 50.6 & 49.4 \\
Total assets (\$m) & $2,553,803$ & 438,231 & 85.4 & 14.6 \\
Average employment (no.) & 753 & 6 & & \\
\hline
\end{tabular}

Notes: ${ }^{(a)}$ Large=management units which employ 200 or more persons or have assets worth more than $\$ 200 \mathrm{~m}$, $\mathrm{SME}=$ management units which employ less than 200 persons and do not have assets worth more than $\$ 200 \mathrm{~m}$.

Source: ABS Business Operations and Industry Performance, Australia, 2000-2001, cat 8140.0.

This economy-level data on firm size was then disaggregated in industry-level data in order to understand the distribution of firm size across different industries. As can be seen from Table 2, SMEs are dominant in all of the industry classifications for which data is available, with large firms contributing a larger-than-average proportion of firms in only a few industries such as mining; manufacturing; finance and insurance; and electricity, gas and water and communication services. Some industries appear to have a highly skewed distribution of firm sizes: retail trade, for example, has a very small number ( 0.2 per cent) of huge firms (with average employment of 1,988 people). Conversely, other industries are less-widely dispersed: the utilities (water, gas, and electricity) industry classification has a high proportion of large firms (30.9 per cent) in the industry, but the average size of the firms is not large (724 people). At the same time, the proportion of SMEs in the industry and their average employment are quite high $(69.1$ per cent and 18 respectively).

16 This figure covers all industries except agriculture, forestry and fishing, general government administration and defence. Including the primary produce industry and self-employed increases the proportion of SMEs. 
Table 2: Average employment and percentage distribution of firms by industry, Australia, 2000-2001

\begin{tabular}{|c|c|c|c|c|c|}
\hline & \multirow[t]{2}{*}{ Industry } & \multicolumn{2}{|c|}{ Average employment } & \multicolumn{2}{|c|}{$\begin{array}{l}\text { Distribution of firms by } \\
\text { size }\end{array}$} \\
\hline & & Large (no.) & SME (no.) & Large (\%) & SME (\%) \\
\hline A & Agriculture, Forestry and Fishing & na & na & na & na \\
\hline B & Mining & 481.0 & 11.2 & 6.4 & 93.6 \\
\hline C & Manufacturing & 656.8 & 10.5 & 1.4 & 98.6 \\
\hline $\mathrm{D}$ & Electricity, Gas and Water Supply & 723.5 & 17.7 & 30.9 & 69.1 \\
\hline $\mathrm{E}$ & Construction & 621.6 & 3.6 & 0.1 & 99.9 \\
\hline $\mathrm{F}$ & Wholesale Trade & 555.2 & 7.4 & 0.5 & 99.5 \\
\hline G & Retail Trade & 1988.4 & 5.5 & 0.2 & 99.8 \\
\hline $\mathrm{H}$ & $\begin{array}{l}\text { Accommodation, Cafes and } \\
\text { Restaurants }\end{array}$ & 622.2 & 10.9 & 0.4 & 99.6 \\
\hline 1 & Transport and Storage & 1211.8 & 5.7 & 0.5 & 99.5 \\
\hline J & Communication Services & na & na & na & na \\
\hline K & Finance and Insurance & 541.2 & 4.0 & 2.1 & 97.9 \\
\hline L & Property and Business Services & 606.4 & 4.9 & 0.3 & 99.7 \\
\hline M & $\begin{array}{l}\text { Government Administration and } \\
\text { Defence }\end{array}$ & na & na & na & na \\
\hline $\mathrm{N}$ & Education & na & na & na & na \\
\hline $\mathrm{O}$ & Health and Community Services & na & na & na & na \\
\hline$P$ & Cultural and Recreational Services & 694.0 & 6.8 & 0.5 & 99.5 \\
\hline Q & Personal and Other Services & 538.9 & 4.4 & 0.2 & 99.8 \\
\hline & All available industries(a) & 770.1 & 7.7 & 0.5 & 99.5 \\
\hline
\end{tabular}

Data on firm-level applications for IP registrations was then collected from IP Australia, which is the government agency responsible for administering and granting patents, trade marks and designs. ${ }^{17}$ This was then matched across to data from two proprietary enterprise datasets: Australia OnDisc and IBISWorld Australia. The former is a Yellow Pages listing of all firms in Australia (including an industry code relating to their main

\footnotetext{
${ }^{17}$ We have access to firm-level data on IP registrations in Australia due to the fact that IP Australia is the major financial contributor to the operation of IPRIA at the University of Melbourne. Only applicants whose primary address was in Australia have been included in the analysis. This excludes a large number of overseas applicants.
} 
areas of operation ${ }^{18}$ ), while the latter is a commercial database on the firm characteristics of the largest 2,500 firms (by revenue) in Australia.

Disaggregation of IP applicants by enterprise size and industry was undertaken by matching the names of applicants across to firm-level data in a two stage process: first, IP data was matched across to large companies listed in the IBISWorld database, and second, the remaining IP data were matched across to SMEs listed in the AOD data base. This approach was used because IBISWorld only contains data on all large firms in Australia. ${ }^{19}$ The results of the matching process are presented in Table 3 . The data suggest that a substantial proportion of all patents ( 21.3 per cent), trade marks ( 34.5 per cent) and designs (22.5 per cent) could not be matched across to firm-specific datasets.

Furthermore, a large proportion of the total number of IP applications was found to be applied for by individuals rather than companies.

Table 3: Matching rates for IP applications from Australian based applicants, 1989 to 2001

\begin{tabular}{|c|c|c|c|c|c|c|}
\hline \multirow[t]{2}{*}{ IP right } & \multicolumn{4}{|c|}{ Company } & \multirow[t]{2}{*}{ Individuals } & \multirow{2}{*}{$\begin{array}{c}\text { Total } \\
\text { Australian } \\
\text { applications }\end{array}$} \\
\hline & $\begin{array}{r}\text { Matched to } \\
\text { Large } \\
\text { enterprises } \\
(\%)\end{array}$ & $\begin{array}{r}\text { Matched } \\
\text { to SME } \\
(\%)\end{array}$ & $\begin{array}{r}\text { Not } \\
\text { matched } \\
(\%)\end{array}$ & Total (\%) & & \\
\hline Patents & 21.3 & 12.0 & 21.3 & 53.2 & 46.8 & 100.0 \\
\hline Trade marks & 24.1 & 20.3 & 34.5 & 78.9 & 21.1 & 100.0 \\
\hline Designs & 13.2 & 13.4 & 22.5 & 46.1 & 53.9 & 100.0 \\
\hline
\end{tabular}

Note: An application was deemed to be 'Australian' if the residential address of the applicant was located in Australia. Source: IP Australia, IBISWorld, Australia OnDisc.

A sector- and industry-level aggregate ratio of IP applications to company employment was then calculated on the assumption that all "not matched" applications were from SMEs and furthermore that the industry distribution of matched application was an unbiased sample of all applications. Table 4 provides data on the intensity of IP usage, that is, a ratio of IP applications to the number of employees across both selected industries, further disaggregated by large firm - SME sector for the seven year period

\footnotetext{
${ }^{18}$ Data on multi-industry firms.

${ }^{19}$ Note that we assumed that any firm that wasn't listed in the IBISWorld database was an SME.
} 
1994-95 to 2000-01. ${ }^{20}$ It reveals that over all, SMEs have a lower patent application rate, a higher trade mark application rate and an equivalent design application rate to large firms. However, there are marked differences between industries. Specifically, the SME patent rate for mining is considerably lower than the large firm rate, the SME trademark rate for construction, wholesale trade accommodation, cafes and restaurants and cultural and recreational services is considerably lower than the large firm rate, and the SME design rate for construction, wholesale trade, cultural and recreational services and personal and other services is considerably lower than the large firm rate. On the other hand, SME outperform large firms in manufacturing for all types of IP and in electricity, gas and water supply for patents and trade marks.

We are interested to discover whether, after technology characteristics outlined in Figure 1 are controlled for, do IP application rates on average differ by firm size? To assess whether size matters; we regressed 7 years of sector (SME, large firm) by industry data (12 industries) on first, two alternative measures of firm size (the average employment per firm in each sector and industry and a dummy variable for SME versus large firm), and secondly a rather parsimonious set of variables to capture differences in the technical conditions of production and supply. Technical conditions were represented by a series of dummies for industry and value added per employed person, the latter being used to indicate the capital intensity of production. However, since value added per employed person is also correlated with firm size (correlation $\approx 0.3$ ), we estimated the regressions both with and without it.

The results from the estimations for each IP right separately (Table 5, Table 6, Table 7) show that neither measure of firm size was significantly different for patent or trade mark applications per employed person. Surprisingly, however both measures were significant for design application rates and indicated a higher rate for large firms. Not surprisingly, the two types of variables to capture differing technical conditions, the industry dummy variables and value added per employed person, were generally significant and consistent with the expectations formed from Table 4.

\footnotetext{
${ }^{20}$ In this study, we assume that the number of employees in a firm is a measure of potential innovativeness since all inventions arise from people, not machines. It is difficult to find studies, or even any anecdotal evidence, to show that SMEs are potentially less innovative per employee than large companies.
} 
Table 4: Patent, trade mark and design applications per employment, by industry and firm size, Australia, 1994-95 to 2000-01

\begin{tabular}{|c|c|c|c|c|c|c|}
\hline \multirow[t]{2}{*}{ Selected industry } & \multicolumn{2}{|c|}{$\begin{array}{c}\text { Patent } \\
\text { applications }{ }^{(a)} \text { per } \\
1000 \text { employees }\end{array}$} & \multicolumn{2}{|c|}{$\begin{array}{c}\text { Trade mark } \\
\text { applications per } \\
1000 \text { employees }\end{array}$} & \multicolumn{2}{|c|}{$\begin{array}{l}\text { Design applications } \\
\text { per } 1000 \text { employees }\end{array}$} \\
\hline & Large & SME & Large & SME & Large & SME \\
\hline Mining & 1.09 & 0.33 & 1.60 & 1.48 & 0.21 & 0.00 \\
\hline Manufacturing & 1.01 & 1.21 & 5.68 & 13.62 & 0.82 & 1.41 \\
\hline $\begin{array}{l}\text { Electricity, gas and water } \\
\text { supply }\end{array}$ & 0.47 & 1.69 & 2.77 & 5.66 & 0.26 & 0.17 \\
\hline Construction & 0.36 & 0.17 & 1.70 & 1.00 & 0.19 & 0.03 \\
\hline Wholesale trade & 0.82 & 0.20 & 6.80 & 4.05 & 0.67 & 0.23 \\
\hline Retail trade & 0.02 & 0.04 & 0.91 & 1.36 & 0.07 & 0.04 \\
\hline $\begin{array}{l}\text { Accommodation, cafes \& } \\
\text { restaurants }\end{array}$ & 0.00 & 0.02 & 1.82 & 0.80 & 0.00 & 0.01 \\
\hline Transport and storage & 0.12 & 0.03 & 0.13 & 1.47 & 0.03 & 0.02 \\
\hline Finance and insurance & 0.24 & 0.07 & 2.33 & 3.79 & 0.02 & 0.01 \\
\hline Property and business services & 0.59 & 0.35 & 1.75 & 4.36 & 0.02 & 0.14 \\
\hline $\begin{array}{l}\text { Cultural and recreational } \\
\text { services }\end{array}$ & 0.31 & 0.04 & 9.03 & 2.49 & 0.30 & 0.03 \\
\hline Personal and other services & 0.33 & 0.06 & 2.15 & 3.81 & 0.41 & 0.05 \\
\hline Average of above (unweighted) & 0.45 & 0.35 & 3.06 & 3.66 & 0.25 & 0.18 \\
\hline $\begin{array}{l}\text { Average of above (weighted by } \\
\text { employment) }\end{array}$ & 0.46 & 0.32 & 2.92 & 4.29 & 0.28 & 0.29 \\
\hline $\begin{array}{l}\text { All industries } \\
\text { (weighted by employment)(b) }\end{array}$ & 0.49 & 0.28 & 2.77 & 3.75 & 0.26 & 0.25 \\
\hline
\end{tabular}

Notes: (a) Complete standard and petty applications and PCT applications that have entered the national phase. 'Australian' means the address of the applicant was Australia. (b) excludes agriculture, forestry and fishing, all businesses without employees (including self-employed only businesses); and general government.

Source: ABS Cat. No. 8140.0.55.002 Summary of Industry Performance, Australia, Final 2000-01, IP Australia, IBISWorld, Australia OnDisc. 
Table 5: Determinants of patent applications per employed person, 1994-95 to 2000-01

\begin{tabular}{|c|c|c|c|c|c|c|c|c|}
\hline $\begin{array}{l}\text { In(patents per } \\
\text { employed person) }\end{array}$ & Coef. & $\bar{t}$ & Coef. & $\bar{t}$ & Coef. & $\bar{t}$ & Coef. & $\bar{t}$ \\
\hline \multicolumn{9}{|l|}{ Measures of firm size } \\
\hline In (average firm size) & 0.15 & 1.33 & & & -0.03 & -1.28 & & \\
\hline SME & & & -0.72 & -1.40 & & & 0.12 & 1.27 \\
\hline $\begin{array}{l}\text { Measures of technica } \\
\text { conditions } \\
\text { In (value added per } \\
\quad \text { employed person) }\end{array}$ & & & & & 0.56 & 3.57 & 0.56 & 3.55 \\
\hline Mining & 1.58 & 1.25 & 1.64 & 1.30 & -0.45 & -1.41 & -0.45 & -1.41 \\
\hline Manufacturing & 3.08 & 2.45 & 3.16 & 2.51 & 0.65 & 3.50 & 0.63 & 3.38 \\
\hline $\begin{array}{l}\text { Electricity, gas and water } \\
\text { supply }\end{array}$ & -0.16 & -0.13 & -0.04 & -0.04 & -0.03 & -0.09 & -0.05 & -0.15 \\
\hline Construction & 1.54 & 1.23 & 1.54 & 1.22 & -0.18 & -0.99 & -0.18 & -0.98 \\
\hline Wholesale trade & 2.07 & 1.65 & 2.12 & 1.68 & 0.07 & 0.38 & 0.06 & 0.34 \\
\hline Retail trade & -0.72 & -0.57 & -0.61 & -0.48 & 0.03 & 0.16 & 0.01 & 0.05 \\
\hline $\begin{array}{l}\text { Accommodation, cafes \& } \\
\text { restaurants }\end{array}$ & -6.77 & -5.37 & -6.69 & -5.32 & -0.05 & -0.31 & -0.07 & -0.39 \\
\hline Transport and storage & -2.11 & -1.68 & -2.03 & -1.62 & -0.44 & -2.29 & -0.45 & -2.32 \\
\hline Finance and insurance & 0.13 & 0.10 & 0.12 & 0.10 & -0.36 & -1.81 & -0.36 & -1.8 \\
\hline $\begin{array}{l}\text { Property and business } \\
\text { services }\end{array}$ & 2.25 & 1.79 & 2.26 & 1.80 & 0.10 & 0.55 & 0.10 & 0.54 \\
\hline $\begin{array}{l}\text { Cultural and recreational } \\
\text { services }\end{array}$ & -0.28 & -0.22 & -0.23 & -0.18 & -0.14 & -0.82 & -0.15 & -0.86 \\
\hline Constant & -3.65 & -3.70 & -2.72 & -2.94 & 2.22 & 3.67 & 2.06 & 3.91 \\
\hline Adj. R & 0.33 & & 0.33 & & 0.45 & & 0.45 & \\
\hline Obs. & 166 & & 166 & & 166 & & 166 & \\
\hline Est method & OLS & & OLS & & OLS & & OLS & \\
\hline
\end{tabular}

Notes: Missing industry is Personal and Other Services. (a) Complete standard and petty applications and PCT applications that have entered the national phase. 'Australian' means the address of the applicant was Australia. (b) excludes agriculture, forestry and fishing, all businesses without employees (including self-employed only businesses); and general government.

Source: ABS Cat. No. 8140.0.55.002 Summary of Industry Performance, Australia, Final 2000-01, IP Australia, IBISWorld, Australia OnDisc. 
Table 6: Determinants of trade mark applications per employed person, 1994-95 to 2000-01

\begin{tabular}{|c|c|c|c|c|c|c|c|c|}
\hline $\begin{array}{l}\text { In(trade mark per } \\
\text { employed person) }\end{array}$ & Coef. & $\mathbf{t}$ & Coef. & $\mathbf{t}$ & Coef. & $\mathbf{t}$ & Coef. & $\mathbf{t}$ \\
\hline \multicolumn{9}{|l|}{ Measures of firm size } \\
\hline In (average firm size) & -0.03 & -0.58 & & & -0.12 & -2.05 & & \\
\hline SME & & & 0.02 & 0.09 & & & 0.38 & 1.41 \\
\hline $\begin{array}{l}\text { Measures of technica } \\
\text { conditions } \\
\text { In (value added per } \\
\quad \text { employed person) }\end{array}$ & & & & & 1.15 & 2.51 & 0.97 & 2.08 \\
\hline Mining & -0.69 & -1.36 & -0.70 & -1.38 & -2.66 & -2.85 & -2.38 & -2.50 \\
\hline Manufacturing & 1.21 & 2.38 & 1.19 & 2.35 & 0.68 & 1.24 & 0.71 & 1.27 \\
\hline $\begin{array}{l}\text { Electricity, gas and water } \\
\text { supply }\end{array}$ & -0.92 & -1.81 & -0.94 & -1.86 & -2.77 & -3.10 & -2.56 & -2.76 \\
\hline Construction & -0.73 & -1.44 & -0.73 & -1.44 & -1.26 & -2.32 & -1.18 & -2.14 \\
\hline Wholesale trade & 0.69 & 1.36 & 0.68 & 1.35 & 0.20 & 0.36 & 0.25 & 0.45 \\
\hline Retail trade & -0.88 & -1.72 & -0.90 & -1.77 & -0.45 & -0.84 & -0.60 & -1.14 \\
\hline $\begin{array}{l}\text { Accommodation, cafes \& } \\
\text { restaurants }\end{array}$ & -0.79 & -1.56 & -0.80 & -1.59 & -0.49 & -0.96 & -0.60 & -1.16 \\
\hline Transport and storage & -2.01 & -3.97 & -2.03 & -4.00 & -2.64 & -4.71 & -2.59 & -4.52 \\
\hline Finance and insurance & 0.06 & 0.11 & 0.06 & 0.11 & -0.58 & -0.99 & -0.47 & -0.78 \\
\hline $\begin{array}{l}\text { Property and business } \\
\text { services }\end{array}$ & 0.02 & 0.04 & 0.02 & 0.04 & -0.34 & -0.65 & -0.29 & -0.55 \\
\hline $\begin{array}{l}\text { Cultural and recreational } \\
\text { services }\end{array}$ & 0.52 & 1.03 & 0.52 & 1.02 & 0.29 & 0.57 & 0.29 & 0.56 \\
\hline Constant & 1.07 & 2.68 & 0.96 & 2.56 & 5.40 & 3.04 & 4.10 & 2.64 \\
\hline Adj. R & 0.25 & & 0.25 & & 0.27 & & 0.26 & \\
\hline Obs. & 166 & & 166 & & 166 & & 166 & \\
\hline Est method & OLS & & OLS & & OLS & & OLS & \\
\hline
\end{tabular}

Notes: Missing industry is Personal and Other Services. (a) Complete standard and petty applications and PCT applications that have entered the national phase. 'Australian' means the address of the applicant was Australia. (b) excludes agriculture, forestry and fishing, all businesses without employees (including self-employed only businesses); and general government.

Source: ABS Cat. No. 8140.0.55.002 Summary of Industry Performance, Australia, Final 2000-01, IP Australia, IBISWorld, Australia OnDisc. 
Table 7: Determinants of design applications per employed person, 1994-95 to 2000-01

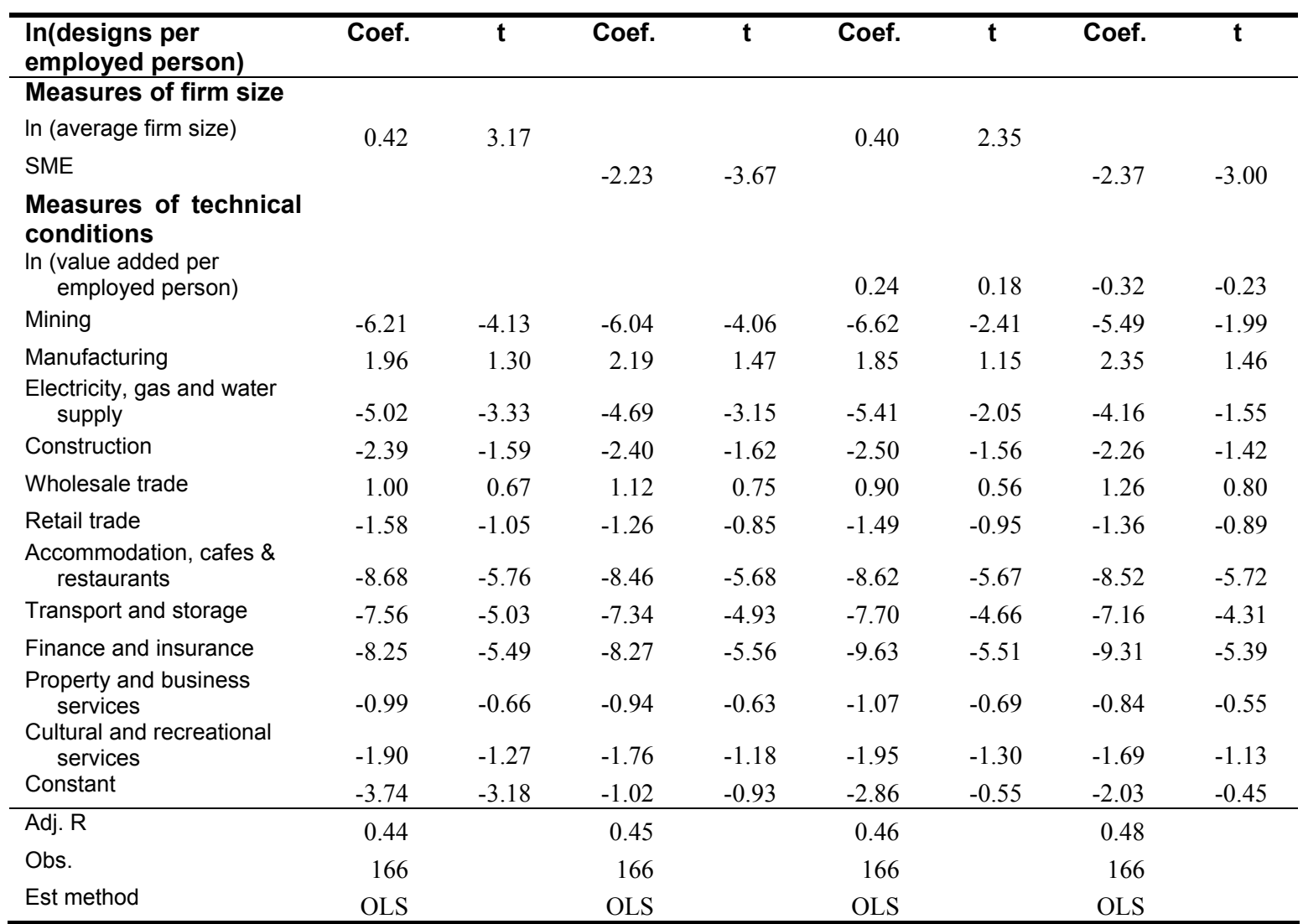

Notes: Missing industry is Personal and Other Services. (a) Complete standard and petty applications and PCT applications that have entered the national phase. 'Australian' means the address of the applicant was Australia. (b) excludes agriculture, forestry and fishing, all businesses without employees (including self-employed only businesses); and general government.

Source: ABS Cat. No. 8140.0.55.002 Summary of Industry Performance, Australia, Final 2000-01, IP Australia, IBISWorld, Australia OnDisc.

We were a little surprised to discover that both the rates for patents and trade marks did not differ systematically by sector so we investigated the possibility that the patents applied for by SMEs represent lower quality inventions than the large firm sector and to investigate this we estimated the seal (grant) and renewal rates by sector. Table 8 shows that per cent of patent applications from the period 1989 to 1994 that had been sealed by August 2003 (we assume that most unsealed patents by this time would have been examined) and the percentage that were still active during August 2003. 
We can reasonably assume that the patent for an invention that has been sealed and continues to be renewed has value to the owner greater or equal than the renewal fees. ${ }^{21}$ Our data shows that a considerably lower proportion of SMEs inventions, or the legal rights pertaining to these inventions, pass the examination threshold than large company inventions. Put another way, there is evidence that SMEs inventions are less valuable than large company inventions. Once passed however, the probability that the patent will continue to be renewed is about the same for both sectors.

\footnotetext{
${ }^{21}$ It is possible that the patent for an invention has a large estimated value to the owner but lack of funds does not permit the owner to pay the renewal fees and the uncertainty surrounding its future value impedes its sale to a more prosperous owner.
} 
Table 9 further disaggregates the matched large and SME patents by industry. It is interesting to see whether the industries where SMEs had higher rates of application manufacturing, electricity, gas and water supply - were merely applying for patents of lower value. In some industries the total number of applications is very small and the data should not be over interpreted. This aside, given the comparable large firm and SME seal and renewal rate for these two industries (shaded), there is no reason to believe that higher levels of SME patenting are associated with lower value patents.

Table 8: Australian patents ${ }^{(a)}$ applied for between 1989 to 1994, seal and renewal rates (at by August 2003)

\begin{tabular}{|c|c|c|c|c|c|}
\hline Sealed status & Large & $\begin{array}{l}\text { SME } \\
\text { matched }\end{array}$ & $\begin{array}{l}\text { SME not } \\
\text { matched }\end{array}$ & $\begin{array}{l}\text { Individ- } \\
\text { uals }\end{array}$ & Total \\
\hline All applications 1989-1994 & 2,673 & 1,659 & 2,839 & 7,051 & 14,222 \\
\hline$\%$ & 100.0 & 100.0 & 100.0 & 100.0 & 100.0 \\
\hline Sealed by Aug 2003 & 1,779 & 924 & 1,740 & 2,961 & 7,404 \\
\hline$\%$ & 66.6 & 55.7 & 61.3 & 42.0 & 52.1 \\
\hline Current at August 2003 & 914 & 390 & 823 & 814 & 2,941 \\
\hline$\%$ & 34.2 & 23.5 & 29.0 & 11.5 & 20.7 \\
\hline
\end{tabular}


Table 9: Australian patents ${ }^{(a)}$ applied for between 1989 to 1994, seal and renewal rates by industry (at August 2003)

\begin{tabular}{|c|c|c|c|c|c|c|c|}
\hline & \multirow[t]{2}{*}{ Industry } & \multicolumn{2}{|c|}{ Seal rates } & \multicolumn{2}{|c|}{ Renewal rate } & \multicolumn{2}{|c|}{$\begin{array}{c}\text { Number of } \\
\text { applications }\end{array}$} \\
\hline & & Large & SME & Large & SME & Large & SME \\
\hline & & $\%$ & $\%$ & $\%$ & $\%$ & no. & no. \\
\hline$B$ & Mining & 59.8 & 50.0 & 33.6 & 50.0 & 107 & 10 \\
\hline C & Manufacturing & 57.5 & 55.8 & 26.3 & 23.2 & 543 & 826 \\
\hline $\mathrm{D}$ & $\begin{array}{l}\text { Electricity, Gas and Water } \\
\text { Supply }\end{array}$ & 72.7 & 87.5 & 31.8 & 37.5 & 44 & 8 \\
\hline$E$ & Construction & 64.3 & 56.2 & 39.3 & 14.6 & 28 & 89 \\
\hline$F$ & Wholesale Trade & 82.9 & 56.8 & 30.4 & 28.1 & 158 & 199 \\
\hline G & Retail Trade & 50.0 & 49.1 & 25.0 & 20.0 & 4 & 55 \\
\hline I & $\begin{array}{l}\text { Accommodation, Cafes and } \\
\text { Restaurants }\end{array}$ & 81.8 & 66.7 & 45.5 & 33.3 & 11 & 3 \\
\hline $\mathrm{J}$ & Transport and Storage & 80.6 & 50.0 & 20.8 & 30.0 & 72 & 10 \\
\hline K & Communication Services & 53.8 & 63.6 & 30.8 & 45.5 & 26 & 11 \\
\hline $\mathrm{L}$ & Finance and Insurance & 69.6 & 55.2 & 42.0 & 20.4 & 369 & 328 \\
\hline M & Property and Business Services & 0.0 & 40.0 & 0.0 & 20.0 & 1 & 10 \\
\hline $\mathrm{N}$ & $\begin{array}{l}\text { Government Administration and } \\
\text { Defence }\end{array}$ & 61.3 & 68.2 & 30.5 & 40.9 & 266 & 22 \\
\hline $\mathrm{O}$ & Education & 72.7 & 75.0 & 36.4 & 12.5 & 11 & 8 \\
\hline \multirow[t]{2}{*}{$P$} & Health and Community Services & 50.0 & 28.6 & 0.0 & 14.3 & 2 & 7 \\
\hline & Total & 66.6 & 55.7 & 34.2 & 23.5 & 2,673 & 1,659 \\
\hline
\end{tabular}

Note: (a) Complete standard and petty applications and PCT applications that have entered the national phase 'Australian' means the Complete application either originated in Australia or the address of the applicant was Australia. Sources: IP Australia, IBISWorld data, Australia OnDisc.

\section{Discussion of the Results}

Our results indicate that on balance SMEs apply for patents and trade marks at the same rate, given their innovative potential, as large enterprises. This finding should however be qualified on account of the rudimentary method we have employed to assign IP applications to companies and to control for the differential effects of technology. ${ }^{22}$ Nonetheless, given this is our best estimate, it implies that the size of a firm's resources may not be as critical to the patenting and trademarking decision as has previously thought. However, there does appear to be significant differences in the SME to large ratio between industries that we cannot account for and we must entertain the possibility that small size disadvantages exist in certain niches. In particular, SMEs in industries

\footnotetext{
${ }^{22}$ Both methods are however a significant advance over existing studies which have merely presented IP counts by firm size and have not been able to control for any industry effects.
} 
other than manufacturing and electricity, gas and water supply appear to have somewhat lower rates of patenting than their large counterparts.

We reiterate the qualifications mentioned above about the robustness of the findings. The extent to which the efficiency of the IP system matters depends on the extent of market failure in the production of innovative services in the particular sector and industry. If the marginal cost of producing items with embodied intellectual capital is close to the average cost, and subsequently the social benefits are equivalent to private benefits at the margin, then there is little welfare enhancing role for a legally based IP appropriation mechanism. As such, we would not be duly concerned about low rates of patenting and trademarking in these industries and sectors. Furthermore, before we become overly concerned about the IP usage rate for SMEs in those industries where their IP applications rates are below the large firm rate, we should acquire some measure of their other forms of appropriability.

\section{Conclusion}

Efficiency requires that SME innovative potential is not hindered by artificial constraints, such as anti-competitive practices and that, subject to the presence of positive externalities, it is publicly supported through for example, enhanced forms of appropriation or subsidisation of the costs of innovation. ${ }^{23}$ The belief that there are generic disadvantages faced by SMEs has created a tradition among governments around the world for the provision of special programs to encourage SME innovation. In Australia for example, the Federal Government has injected an additional \$200 million per annum in support for innovation in the SME sectors.

This paper has looked at the extent to which SMEs appear to be disadvantaged in the innovation process through their use of the intellectual property (IP) system and not found strong positive evidence. We cannot rule out pockets of disadvantage in specific areas. It is possible that many of the anecdotally cited disadvantages of using the IP system claimed by the SME sector apply equally to large firms.

\footnotetext{
${ }^{23}$ This arises from the view that there is an economic failure in the market for innovative services and without some form of public support, the level of innovative activity will be sub-optimal.
} 


\section{Appendix: Data Set Construction}

To investigate the extent of IP usage by SMEs we constructed a customised data set from available administrative data bases. The ABS does not collate IP data, and IP Australia does not collect details on company size or industry. Constructing the data set required us to computer match company names from the IP Australia data base on patent, trade mark and design applications, to two enterprise data sets: IBISWorld, which includes data on employees, turnover, profits, assets and industry, inter alia for the largest 2,000 to 3,000 enterprises (and their subsidiaries) in Australia ${ }^{24}$, and the Australia OnDisc (AOD) data base, which has multiple industry classifications on both large and small enterprises in Australia.

Companies classified as large by IBISWorld, were removed from the AOD database to give us an SME data base. Only industry classification was available for the latter and there was no financial data for SMEs. The AOD database gives multiple industry classifications for companies, unlike the IBISWorld database which only gives the main industry. In order to make the databases comparable, we prioritised the AOD industries based on our knowledge of companies. If an industry had a manufacturing classification, we deemed it to be mainly manufacturing and ignored the other classifications which were often, business services and wholesale trade.

About 40 per cent of Australian company patent applications ${ }^{25}$ matched across to IBISWorld companies. A patent application is deemed 'Australian' if the application originated in Australia or the designated country of owner was Australia. A further 20 per cent of Australian company patent applicants matched across to the SME AOD data base. The remaining 40 per cent of applicants remain unmatched. The percentage distribution of technology classes of these unmatched applicants indicate that they are similar to the matched SME applicants. About 80 per cent of trade mark applications are taken out in a

\footnotetext{
${ }^{24}$ Approximately 80 per cent of the IBISWorld companies meet the ABS definition of a 'large' firm. Financial information is only included for the Australian parent, or the highest Australian accounting unit, in the case of foreign owned companies.

${ }^{25}$ These are provisional standard applications or PCT applications that have entered the national phase.
} 
company name ${ }^{26}$. Of these, we matched just over half to either IBISWorld or the AOD SME listings. Just under 50 per cent of design applications are taken out by companies and of these about 60 per cent were matched across to either IBISWorld or SME AOD companies.

Table 10 shows the percentage of Australian enterprises that applied for at least one patent, trade mark or design according to whether it was a large or medium size firm.

Table 10: Percentage of enterprise that that applied for at least one patent ${ }^{(a)}$, trade mark or design application by size of firm, 1989-2002

\begin{tabular}{lrrrr}
\hline & \multicolumn{1}{c}{ Large } & Medium & Unknown & Total \\
Patents & 6.1 & 1.5 & 0.8 & 5.1 \\
Trade marks & 26.4 & 15.7 & 6.3 & 23.8 \\
Designs & 4.0 & 1.2 & 0.5 & 3.4 \\
Average number of & 1367 & 314 & 61 & 1742 \\
enterprises & & &
\end{tabular}

Note: (a) Complete standard applications and PCT applications that have entered the national phase.

Sources: IP Australia, IBISWorld data, Australia OnDisc.

${ }^{26}$ IP Australia do not separate companies from individual applicants and we have designated an applicant 'individual' if the first word in their name was a recognisable boys or girls name. 
Figure 1: The effect of firm size on innovation and IP usage

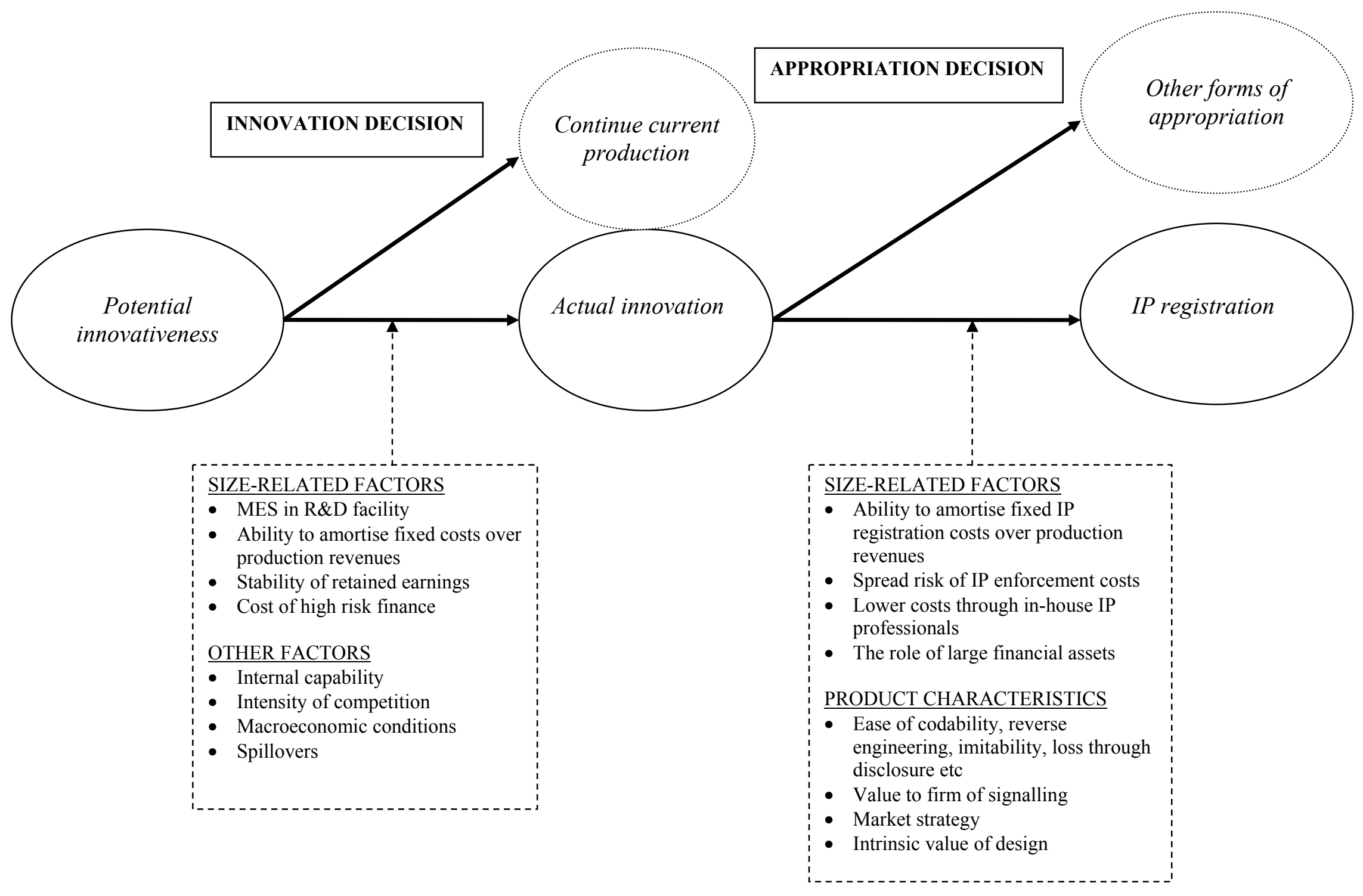




\section{References}

Acs, Z. J. and Audretsch, D. B. (1993), Analysing innovation output counts: The US experience, In New Concepts in Innovation Output Measurement (Eds, Kleinknecht, A. and Bain, D.) St Martin's Press, Houndmills, Basingstoke and London, pp. 10-41.

Arrow, K. J. (1983), Innovation in large and small firms, In Entrepreneurship (Ed, Ronen, J.) Lexington Books.

Arundel, A. and Kabla, I. (1998), What percentage of innovations are patented? Empirical estimates for European firms, Research Policy, 27, 127-141.

Boldrin, M. and Levine, D. K. (2004), The case against intellectual monopoly, International Economic Review, 45, 327-350.

CHI Research, I. (2003) Small Serial Innovators: The Small Firm Contribution to Technical Change, In mimeo (Ed, Advocacy, R. f. S. O. o.) Haddon Heights, New Jersey.

Cohen, W. M. (1995), Empirical studies of innovative activity, In Handbook of the Economics of Innovation and Technical Change (Ed, Stoneman, P.) Blackwell, Oxford UK \& Cambridge USA.

Cohen, W. M. and Levinthal, D. A. (1989), Innovation and learning: The two faces of R\&D, Economic Journal, 99, 569-596.

Cohen, W. M., Nelson, R. R. and Walsh, J. P. (2000) Protection their intellectual assets: Appropriability conditions and why US manufacturing firms patent (or not), In NBER Working Paper Series, Vol. 7552 National Bureau of Economic Research.

Cooter, R. D. and Rubinfeld, D. L. (1989), Economic analysis of legal disputes and their resolution, Journal of Economic Literature, 27, 1067-1097. 
Gans, J. S., Hsu, D. H. and Stern, S. (2002), When does start-up innovation spur the creative gale of destruction?, RAND Journal of Economics, 33, 571-586.

Hanel, P. (2004) Current intellectual protection practices by manufacturing firms in Canada, In mimeo University of Sherbrooke.

Heller, M. and Eisenberg, R. S. (1998), Can patents deter innovation? The anticommons in biomedical research., Science, 280, 698-701.

IPAC (2003) The Enforcement of Patent Rights, UK Intellectual Property Advisory Committee.

Iversen, E. (2002) Norwegian SMEs and the IPR-system: Exploration and Analysis, In Studies in Technology, Innovation and Economic Policy [STEP] Oslo.

Jensen, P. and Webster, E. (2004) Examining Biases in Measures of Firm Innovation, In Melbourne Institute working paper series, Vol. 05/04 Melbourne Institute of Applied Economic and Social Research, University of Melbourne.

Kleinknecht, A., Reijnen, J. O. N. and Smits, W. (1993), Collecting literature based innovation output indicators. The experience in the Netherlands, In New Concepts in Innovation Output Measurement (Eds, Kleinknecht, A. and Bain, D.) S t Martin's Press, Hampshire and London, pp. 42-84.

Lerner, J. (1999), The government as venture capitalist: the long-run impact of the SBIR program, Journal of Business, 72, 285.

Levin, R. C., Cohen, W. M. and Mowery, D. C. (1987a), Firm Size and R\&D Intensity: A Re-examination, Journal of Industrial Economics, 35, 543-565.

Levin, R. C., Klevorick, A. K., Nelson, R. R. and Winter, S. G. (1987b), Appropriating the Returns from Industrial Research and Development, Brookings Papers on Economic Activity, 3, 783-820. 
Levin, R. C. and Reiss, P. (1984), Tests of a Schumpeterian model of R\&D and market structure, In $R \& D$, Patents and Productivity (Ed, Griliches, Z.) University of Chicago Press, Chicago and London, pp. 175-208.

Macdonald, S. (2004), When means become ends: considering the impact of patent strategy on innovation, Information Economics and Policy, 16, 135-158.

Mansfield, E., Schwartz, M. and Wagner, S. (1981), Imitation costs and patents: An empirical study, In Innovation, Technology and the Economy. The Selected Essays of Edwin Mansfield (Ed, Mansfield, E.) Edward Elgar, [1995], Aldershot, UK. Brookfield, US, pp. 253-264.

Patel, P. and Pavitt, K. (Eds.) (1995) Patterns of Technological Activity: their Measurement and Interpretation, Blackwell, Oxford, UK and Cambridge, USA.

Rogers, M. (2004), Networks, Firms Size and Innovation, Small Business Economics, 22, 141-153.

Rubinfeld, D. and Maness, R. (2004) The Strategic Use of Patents: Implications for Antitrust, In Antitrust, Patent and Copyright Conference Paris.

Scherer, F. M. and Ross, D. (1990) Industrial Market Structure and Economic Performance, Houghton-Mifflin, New York.

Schumpeter, J. A. (1934) The Theory of Economic Development: An Inquiry into Profits, Capital, Credit, Interest and the Business Cycle, Harvard University Press, Cambridge:MA.

Schumpeter, J. A. (1976) Capitalism, Socialism and Democracy, George Allen \& Unwin, [1943], London, Boston, Sydney.

Shapiro, C. (2001), Navigating the Patent Thicket: Cross Licenses, Patent Pools and Standard Setting, In Innovation Policy and the Economy, Vol. I, (Eds, Jaffe, A., Lerner, J. and Stern, S.) The MIT Press, Cambridge, Mass. 
Wallsten, S. J. (2000), The effects of government-industry R\&D programs on private $\mathrm{R} \& \mathrm{D}$ : the case of the Small Business Innovation Research program, RAND Journal of Economics, 31, 82-100. 